\title{
PENENTUAN LOKASI BUDI DAYA RUMPUT LAUT (Euchema spp.) BERDASARKAN PARAMETER LINGKUNGAN DI PERAIRAN KECAMATAN MORO, PROVINSI KEPULAUAN RIAU
}

\author{
I Nyoman Radiarta*), Tri Heru Prihadi*), Adang Saputra*), Joni Hariyadi*), dan Ofri Johan*)
}

\begin{abstract}
ABSTRAK
Penelitian ini bertujuan untuk melakukan identifikasi kelayakan perairan untuk budi daya rumput laut dengan menggunakan metode long line berdasarkan parameter lingkungan di perairan Kecamatan Moro Provinsi Kepulauan Riau. Sebanyak 87 stasiun telah dikumpulkan selama survai lapangan pada bulan Agustus dan Oktober 2004. Data parameter lingkungan dan data penginderaan jauh selanjutnya dianalisis dengan menggunakan sistem informasi geografis dan multi kriteria analisis. Dari total potensial lokasi penelitian seluas $417 \mathrm{~km}^{2}$ (jarak $1 \mathrm{~km}$ dari garis pantai), kategori sangat layak di temukan di perairan sekitar Pulau Sugie dan Pulau Combol seluas $110 \mathrm{~km}^{2}$. Hasil verifikasi dari klasifikasi tingkat kelayakan menunjukkan bahwa sekitar $44 \%$ dari budi daya yang ada menempati kategori sangat layak. Terdapat sekitar $6 \%$ yang menempati perairan dengan kategori tidak layak.
\end{abstract}

ABSTRACT: Seaweed aquaculture site selection based on environmental parameters in adjacent water of Moro Sub District, Riau Island Province. By: I Nyoman Radiarta, Tri Heru Prihadi, Adang Saputra, Joni Hariyadi, and Ofri Johan

\begin{abstract}
This study was conducted to identify suitability site for seaweed culture using long line method based on environmental parameters in adjacent water of Moro Sub District, Riau Island Province. Field observation was primary data sources used in this study that was conducted on August and October 2000. Total of 87 sampling stations were collected during the field survey. Environmental data together with remote sensing data were analyzed using geographic information system and multi criteria analysis. The final result showed that from the total potential site of about $417 \mathrm{~km}^{2}(1 \mathrm{~km}$ buffer from coastline), area around Sugie Island and Combol Island (about $110 \mathrm{~km}^{2}$ ) were classified as highly suitable. The result has been verified with the existing seaweed aquaculture. About $44 \%$ of existing seaweed culture matched with highly suitable site and about $6 \%$ was located in unsuitable site.
\end{abstract}

KEYWORDS: seaweed culture, environment, GIS, multicriteria analysis, Riau

\section{PENDAHULUAN}

Indonesia yang memiliki garis pantai terpanjang kedua di dunia $(81.000 \mathrm{~km})$ dengan karakteristik perairan pantai meliputi perairan dangkal dan lagoon merupakan potensi yang besar bagi pengembangan budi daya rumput laut. Kegiatan budi daya rumput laut telah menunjukkan kontribusi nyata bagi pendapatan daerah maupun nasional.
Berdasarkan produksi rumput laut 11 tahun terakhir menunjukkan kenaikan dari 102.000 ton pada tahun 1994 menjadi 866.000 ton pada tahun 2005 , dengan nilai total ditahun 2005 mencapai US\$ 128 juta (FAO, 2007; Direktorat Jenderal Perikanan Budidaya, 2006). Dari total produksi rumput laut di Indonesia sebagian besar berasal dari perairan Bali dan Nusa Tenggara. Besarnya potensi yang dimiliki untuk kegiatan budi daya rumput laut belum

\footnotetext{
*) Peneliti pada Pusat Riset Perikanan Budidaya, Jakarta
} 
seluruhnya termanfaatkan dengan baik. Penentuan lokasi yang tepat bagi kegiatan budi daya rumput laut merupakan langkah awal yang harus dilakukan untuk dapat menjamin keberlangsungan usaha budi daya yang sesuai dengan kondisi lingkungan (GESAMP, 2001). Tiensongrusmee (1990) mengemukakan beberapa faktor yang harus diperhatikan dalam kajian kelayakan perairan untuk budi daya rumput laut yaitu: faktor risiko (keamanan, konflik pemanfaatan lahan, dan keterjangkauan), faktor ekologi (ketersediaan benih, keterlindungan lokasi, arus air, kondisi dasar perairan, kedalaman, salinitas, suhu air, dan tingkat polusi), dan faktor sosial ekonomi.

Secara konvensional analisis kelayakan untuk kegiatan budi daya laut dapat dilakukan dengan penilaian secara individu, metode ini bersifat subjektif serta memerlukan waktu dan prosedur yang cukup lama (Giap et al., 2005). Dengan perkembangan teknologi dewasa ini, sistem informasi geografis (SIG) banyak memberikan kemudahan untuk melakukan analisis keruangan (spasial) secara cepat dan sistimatik. Pemanfaatan SIG dalam bidang perikanan budi daya sampai dewasa ini sudah cukup banyak semenjak pertama kali dipublikasikan tahun 1980-an oleh Kapetsky (Kapetsky et al., 1987), antara lain: budi daya ikan laut dengan keramba jaring apung (Pérez et al., 2005), budi daya udang (Karthik et al., 2005), dan budi daya kekerangan (Buitrago et al., 2005; Arnold et al., 2000).

Tujuan dari penelitian ini adalah untuk melakukan identifikasi tingkat kelayakan perairan bagi budi daya rumput laut menggunakan metode long line berdasarkan parameter lingkungan di perairan Kecamatan Moro. Analisis kelayakan perairan dilakukan dengan menggunakan SIC dan multicriteria analisis. Hasil dari penelitian ini diharapkan dapat memberikan gambaran umum bagi pemerintah daerah guna membantu dalam pengambilan keputusan dan penyusunan rencana tata ruang wilayah/pesisir.

\section{BAHAN DAN METODE}

Penelitian telah dilakukan di perairan Kecamatan Moro, Kabupaten Tanjung Balai Karimun, Provinsi Kepulauan Riau. Lokasi penelitian terbentang pada posisi $103^{\circ} 30 \$--$ $104^{\circ} 00 \$$ Bujur Timur dan $0{ }^{\circ} 32 \$-0^{\circ} 55 \$$ Lintang Utara dengan luasan perairan sekitar $1.523 \mathrm{~km}^{2}$ (Gambar 1). Kecamatan Moro dapat dikatakan sebagai suatu kecamatan kepulauan karena terdiri atas pulau-pulau yang jumlahnya mencapai 92 buah (Anonim, 2003). Dari jumlah tersebut baru sekitar 35 pulau yang berpenghuni, sisanya sebanyak 57 pulau belum berpenghuni (terdiri atas daratan atau pulau karang). Dengan memiliki luas lautan yang lebih besar (75\%) dari luas daratan (25\%) serta memiliki banyak perairan dangkal dan lagoon menjadikan perairan di kecamatan ini lokasi yang baik bagi pengembangan budi daya rumput laut. Selain aspek sumber daya alam tersebut, Kecamatan Moro memiliki aspek pemasaran hasil budi daya laut yang cukup baik karena lokasinya berdekatan dengan Batam dan Singapura.

Data yang dikumpulkan dalam penelitian ini terdiri atas data lapangan dan data sekunder. Pengumpulan data lapangan dilakukan pada bulan Agustus dan Oktober 2004. Pengumpulan data pada bulan yang berbeda diharapkan dapat mewakili dua musim yaitu musim panas dan musim hujan. Metode yang dipakai dalam penelitian ini adalah metode survai yang dirancang berdasarkan SIG. Penentuan lokasi pengamatan dilakukan dengan teknik acak sederhana (Simple random sampling) (Morain, 1999). Inisiasi survai dan data sekunder digunakan sebagai dasar untuk menentukan lokasi titik pengamatan. Sebanyak 87 titik pengamatan telah berhasil dikumpulkan (Gambar 1). Pengambilan data lapangan dilakukan pada kisaran waktu pukul 09.0015.00 WIB. Data yang dikumpulkan dalam penelitian ini terdiri atas kedalaman, kecerahan, kecepatan arus, dan tinggi gelombang.

Data sekunder yang dikumpulkan diantaranya berupa peta dasar, data statistik, laporan dari dinas setempat, dan data kedalaman perairan. Peta dasar yang digunakan didigitasi secara on screen dari citra satelit Landsat 7: path/row: 125/060, April 2000 dan 125/059, Juli 2002 keluaran LAPAN. Tema utama dari peta dasar yang diambil meliputi: garis pantai dan ekosistem pesisir (mangrove dan terumbu karang). Data kedalaman perairan didigitasi dari peta bathymetri keluaran Dinas Hidro Oseanografi. Diagram alur analisis kelayakan lahan budi daya rumput laut disajikan pada Gambar 2.

\section{Penentuan Skor dan Pembobotan}

Penentuan lokasi budi daya rumput laut dapat dianalisis dengan memperhatikan berbagai faktor: lingkungan, risiko, sosial 


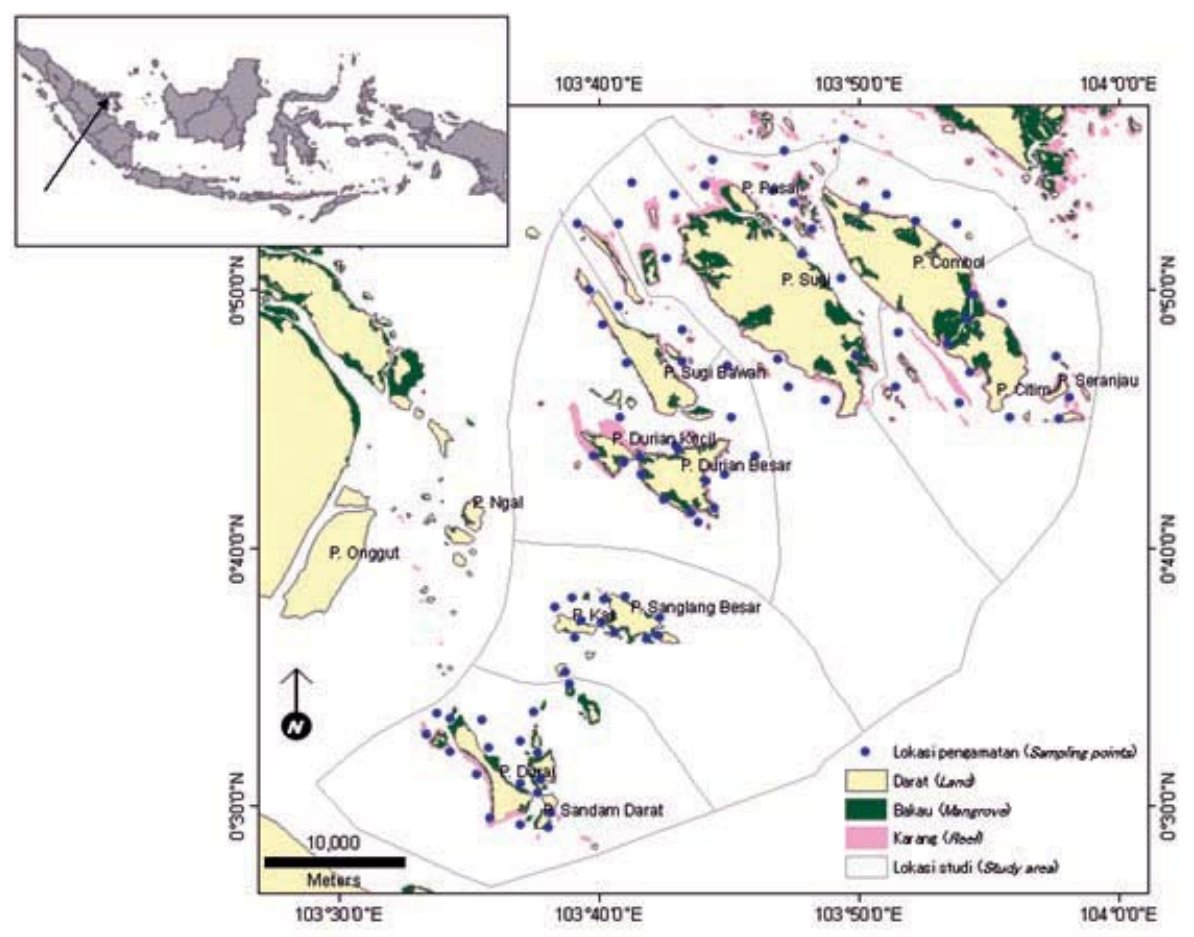

Gambar 1. Tampilan umum lokasi penelitian dan distribusi lokasi pengambilan data lapangan Figure 1. General features of study area, and distribution of sampling points

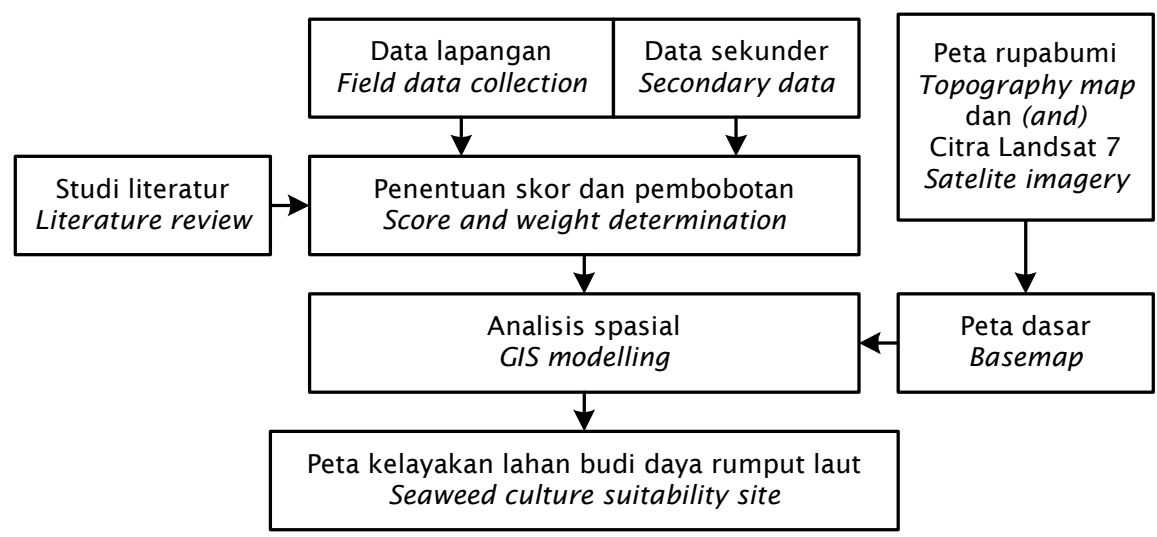

Gambar 2. Diagram alur analisis penentuan lokasi budi daya rumput laut

Figure 2. Schematic model for seaweed culture site selection

ekonomi, dan infrastruktur (Mubarak et al., 1990; Tiensongrusmee, 1990), namun dalam penelitian ini hanya memfokuskan pada faktor lingkungan yang berpengaruh besar bagi pengembangan budi daya rumput laut di perairan Kecamatan Moro. Faktor lingkungan yang berpengaruh bagi kegiatan budi daya rumput laut meliputi berbagai jenis parameter. 
Namun karena terbatasnya ketersediaan data yang ada, dalam penelitian ini hanya berdasarkan empat parameter meliputi: kecerahan perairan, kedalaman, kecepatan arus, dan keterlindungan (kondisi gelombang).

Penentuan skor untuk masing-masing parameter berdasarkan efek dari parameter tersebut bagi budi daya rumput laut. Penelitian ini menggunakan skor 1-4 (Giap et al., 2005; Salam et al., 2003). Skor 4 adalah sangat layak, sedangkan 1 adalah tidak layak bagi kegiatan budi daya rumput laut. Kriteria yang digunakan untuk penyusunan matrik kesesuaian mengacu pada Mubarak et al. (1990) dan Tiensongrusmee (1990). Tabel 1 menyajikan matrik kesesuaian untuk penentuan kelayakan lahan budi daya rumput laut.

Sistem pembobotan sangat mempengaruhi hasil analisis kelayakan perairan. Pembobotan parameter dipenelitian ini berdasarkan studi literatur (expert opinions). Parameter yang mempunyai pengaruh dominan dan relatif tidak dapat diubah memiliki faktor pembobot yang paling besar, sebaliknya parameter yang kurang dominan memiliki faktor pembobot yang lebih kecil. Penelitian ini mengunakan Analytical hierarchy process (AHP) yang dikenal dengan pair wise comparison (Saaty, 1977; Malczewski, 1999) untuk menentukan bobot dari masing-masing parameter (Tabel 2). Keunggulan dari teknik ini adalah bobot yang dibuat dapat diuji dengan melihat rasio konsistensi (consistency ratio/CR). CR baru dapat diterima jika kurang dari 0,1 ; jika nilai tersebut lebih besar maka harus dilakukan pembobotan ulang.

\section{Analisis Spasial}

Data yang dikumpulkan pada sampling yang berbeda (bulan Agustus dan Oktober) seluruhnya digabungkan sehingga menjadi satu kesatuan data, yang selajutnya dilakukan

Tabel 1. Kesesuaian parameter lingkungan untuk budi daya rumput laut Table 1. Environmental factors requirement for seaweed culture

\begin{tabular}{lcccc}
\hline & \multicolumn{4}{c}{ Tingkat kelayakan (Suitability score) } \\
\cline { 2 - 5 } Parameter & $\begin{array}{c}\text { Sangat layak } \\
\text { Highly } \\
\text { suitable } \\
\mathbf{4}\end{array}$ & $\begin{array}{c}\text { Layak } \\
\text { Suble } \\
\mathbf{3}\end{array}$ & $\begin{array}{c}\text { Cukup layak } \\
\text { Marginally } \\
\text { suitable } \\
\mathbf{2}\end{array}$ & $\begin{array}{c}\text { Tidak layak } \\
\text { Not suitable } \\
\mathbf{1}\end{array}$ \\
\hline $\begin{array}{l}\text { Kedalaman (m) } \\
\text { Bathymetry } \\
\text { Kecerahan (m) }\end{array}$ & $1--10$ & $10--15$ & $15--20$ & $<1 \&>20$ \\
$\begin{array}{l}\text { Transparency } \\
\text { Arus (cm/s) } \\
\text { Water current } \\
\text { Gelombang }(\mathrm{cm}) \\
\text { Wave height }(\mathrm{cm})\end{array}$ & $? 3$ & $2--3$ & $1--2$ & $<1$ \\
\hline
\end{tabular}

Tabel 2. Matrik penentuan bobot untuk analisis pemilihan lokasi budi daya rumput laut Table2. Pair wise comparison matrix for assessing the relative important of criteria for seaweed culture site selection

\begin{tabular}{lcccccc}
\hline $\begin{array}{c}\text { Faktor lingkungan } \\
\text { Environmental factors }\end{array}$ & $\begin{array}{c}\text { Kecerahan } \\
\text { Tranparency }\end{array}$ & $\begin{array}{c}\text { Kedalaman } \\
\text { Bathymetry }\end{array}$ & $\begin{array}{c}\text { Arus } \\
\text { Current }\end{array}$ & $\begin{array}{c}\text { Gelombang } \\
\text { Wave height }\end{array}$ & $\begin{array}{c}\text { Bobot } \\
\text { Weight }\end{array}$ \\
\hline Kecerahan (Tranparency) & 1 & $4 / 3$ & 2 & 4 & 0.4 \\
Kedalaman (Bathymetry) & $3 / 4$ & 1 & $3 / 2$ & 3 & 0.3 \\
Arus (Current) & $1 / 2$ & $2 / 3$ & 1 & 2 & 0.2 \\
Gelombang (Wave height) & $1 / 4$ & $1 / 3$ & $1 / 2$ & 1 & 0.1 \\
\hline
\end{tabular}

Consistency Ratio (CR): 0.000, consistency is acceptable 
analisis spasial. Dalam hal ini peta tematik yang dihasilkan akan memberikan gambaran secara umum lokasi penelitian.

Peta tematik parameter lingkungan terlebih dahulu disusun sebelum dilakukan analisis spasial kelayakan perairan budi daya rumput laut. Data lingkungan yang meliputi kecerahan, kecepatan arus, dan kondisi gelombang yang berupa titik telah dikonversi menjadi area (polygon) dengan menggunakan teknik interpolasi inverse distance weighted (Johnson \& McChow, 2001). Sedangkan data kedalaman perairan dinterpolasi dengan triangulated irregular network (Booth, 2000). Analisis spasial seluruhnya dilakukan dengan menggunakan ArcGIS versi 9.0 (The Environmental System Research Institute (ESRI), USA). Tingkat kelayakan lahan bagi kegiatan budi daya rumput laut dihasilkan setelah seluruh parameter di tumpang susunkan (overlay) berdasarkan skor dan bobot dengan menggunakan persamaan di bawah ini:

$$
A_{i}=\frac{\left(\sum_{j} w_{j} x_{i j}\right)}{n}
$$

di mana $A_{i}$ adalah nilai kelayakan perairan, $x_{i j}$ adalah tingkat kesesuaian (score) dari masingmasing parameter, $w_{j}$ adalah nilai pembobot di mana $\Sigma \mathrm{w}_{\mathrm{j}}=1$, dan $\mathrm{n}$ adalah jumlah sistem skor.

Tingkat kelayakan lahan secara utuh diperoleh dari hasil perhitungan di atas, kemudian dikelompokkan berdasarkan kisaran nilai dari masing-masing tingkat kalayakan seperti yang disajikan pada Tabel 3 .

\section{Verifikasi Peta Kelayakan Perairan}

Verifikasi peta kelayakan perairan dilakukan dengan cara membandingkan antara peta kelayakan hasil analisis dengan data sebaran budi daya rumput laut yang ada di lokasi penelitian. Peta sebaran budi daya rumput laut dibuat berdasarkan data yang dikumpulkan selama kegiatan lapangan, peta ini kemudian di-overlay dengan peta kelayakan perairan hasil analisis untuk melihat seberapa besar kegiatan budi daya rumput laut sesuai dengan tingkat kelayakan perairan hasil analisis.

\section{HASIL DAN BAHASAN}

\section{Luasan dan Lokasi Kelayakan Perairan}

Lokasi kegiatan budi daya rumput laut di perairan Kecamatan Moro umumnya ditemukan tidak jauh dari garis pantai dengan menggunakan metode long line. Pemilihan lokasi tersebut akan memberikan kemudahan dalam melakukan aktivitas budi dayanya (meliputi: penanaman, pengontrolan, dan pemanenan). Sehubungan dengan hal tersebut, meskipun peta kesesuaian lahan parameter lingkungan disajikan untuk seluruh lokasi penelitian (sekitar $1.523 \mathrm{~km}^{2}$ ), luasan perairan dari masing-masing parameter sesuai dengan tingkat kelayakan dianalisis hanya berdasarkan perairan dengan jarak $1 \mathrm{~km}$ dari garis pantai (buffer $1 \mathrm{~km}$ ) dengan total luasan potensial sekitar $417 \mathrm{~km}^{2}$. Luasan dan persentase tingkat kelayakan perairan untuk budi daya rumput laut disajikan pada Tabel 4. Gambar 3 menyajikan sebaran spasial data parameter lingkungan (kecerahan, kecepatan arus, tinggi gelombang, dan kedalaman perairan).

Kecerahan perairan sangat mempengaruhi sintasan rumput laut yang dibudidayakan. Rumput laut seperti halnya tumbuhan air lainnya memerlukan sinar matahari sebagai sumber energi untuk fotosintesis bagi pertumbuhannya. Perairan yang keruh akan menghambat pertumbuhan rumput laut. Berdasarkan kecerahan perairan, tingkat kelayakan perairannya terlihat memiliki pola yaitu wilayah bagian selatan memiliki tingkat

Tabel 3. Nilai kesesuaian untuk pemilihan lokasi budi daya rumput laut Table 3. Overall suitability rating score for seaweed culture

\begin{tabular}{lc}
\hline $\begin{array}{c}\text { Tingkat kelayakan } \\
\text { Suitability rating }\end{array}$ & $\begin{array}{c}\text { Kisaran nilai } \\
\text { Score range }\end{array}$ \\
\hline Sangat layak (Highly suitable) & $0.8--1.0$ \\
Layak (Suitable) & $0.6--0.8$ \\
Cukup layak (Marginally suitable) & $0.4--0.6$ \\
Tidak layak (Unsuitable) & $0.0--0.4$ \\
\hline
\end{tabular}


Tabel 4. Luasan dan presentase tingkat kesesuaian perairan untuk budi daya rumput laut (total luasan potensial $417 \mathrm{~km}^{2}$ )

Table 4. Area and different suitability level for seaweed culture (total potential area 417 $\mathrm{km}^{2}$ )

\begin{tabular}{|c|c|c|c|c|c|c|c|c|}
\hline \multirow{2}{*}{$\begin{array}{c}\text { Parameter } \\
\text { lingkungan } \\
\text { Environmental } \\
\text { factors }\end{array}$} & \multicolumn{2}{|c|}{$\begin{array}{l}\text { Sangat layak } \\
\text { Highly suitable }\end{array}$} & \multicolumn{2}{|c|}{$\begin{array}{l}\text { Layak } \\
\text { Suitable }\end{array}$} & \multicolumn{2}{|c|}{$\begin{array}{c}\text { Cukup layak } \\
\text { Marginally suitable }\end{array}$} & \multicolumn{2}{|c|}{$\begin{array}{l}\text { Tidak layak } \\
\text { Not suitable }\end{array}$} \\
\hline & $\left(\mathrm{km}^{2}\right)$ & (\%) & $\left(\mathrm{km}^{2}\right)$ & (\%) & $\left(\mathrm{km}^{2}\right)$ & (\%) & $\left(\mathrm{km}^{2}\right)$ & (\%) \\
\hline $\begin{array}{l}\text { Kecerahan } \\
\text { Transparency }\end{array}$ & 48 & 12 & 71 & 17 & 134 & 32 & 164 & 39 \\
\hline $\begin{array}{l}\text { Arus } \\
\text { Water current }\end{array}$ & 274 & 66 & 32 & 7 & 2 & 1 & 109 & 26 \\
\hline $\begin{array}{l}\text { Gelombang } \\
\text { Wave height }\end{array}$ & 275 & 66 & 81 & 19 & 44 & 11 & 17 & 4 \\
\hline $\begin{array}{l}\text { Kedalaman } \\
\text { Bathymetry }\end{array}$ & 143 & 34 & 86 & 21 & 91 & 22 & 97 & 23 \\
\hline $\begin{array}{l}\text { Total } \\
\text { Overall suitability site }\end{array}$ & 110 & 26 & 136 & 33 & 132 & 32 & 39 & 9 \\
\hline
\end{tabular}

kecerahan yang sangat rendah sedangkan bagian utara memiliki kecerahan yang cukup baik (Gambar 3a). Lokasi dengan kategori tidak layak sebesar $164 \mathrm{~km}^{2}$ ditemukan di sekitar perairan Pulau Durian, Pulau Sangiang Besar, dan Pulau Durai. Perairan yang terletak antara Pulau Sugie Bawah dan Pulau Sugie tergolong kategori cukup layak yaitu sebesar $134 \mathrm{~km}^{2}$ (32\%). Perairan dengan kategori yang sangat layak dan layak terletak antara Pulau Sugie dan Pulau Combol dengan luasan masing-masing $48 \mathrm{~km}^{2}$ (12\%) dan $71 \mathrm{~km}^{2}$ (17\%).

Kecepatan arus merupakan faktor yang dapat mengontrol dan mempengaruhi pertumbuhan rumput laut. Arus berperan penting bagi penyediaan nutrient dalam perairan dan dapat mengontrol peningkatan suhu air (Tiensongrusmee, 1990). Tingkat kelayakan perairan berdasarkan parameter kecepatan arus perairan menunjukkan pola yang mirip dengan parameter kecerahan (Gambar 3b). Perairan dengan kategori sangat layak terletak pada bagian utara lokasi penelitian yang meliputi Pulau Combol, Pulau Sugie, Pulau Sugie Bawah, dan Pulau Durian dengan luasan mencapai $274 \mathrm{~km}^{2}$ (66\%). Pada bagian selatan lokasi penelitian (Pulau Sangiang dan Pulau Durai) tergolong kategori tidak layak dengan luasan sekitar $109 \mathrm{~km}^{2}$ (26\%).
Lokasi yang terlindung merupakan satu persyaratan untuk budi daya rumput laut. Keterlindungan lokasi bisa dilihat dari berbagai aspek antara lain kondisi gelombang dan kondisi kecepatan angin yang berasal dari laut lepas. Lokasi dengan gelombang yang besar umumnya tidak sesuai bagi budi daya rumput laut, karena dapat memindahkan rumput laut dari media budi dayanya serta dapat merusak media budi daya rumput laut yang digunakan. Pengaruh gelombang terhadap media dan rumput laut yang dibudi dayakan dapat diminimalkan dengan cara memasukkan rumput laut kedalam jaring sebelum diikatkan pada long line, seperti yang dilakukan pembudi daya di Parairan Pantai Selatan Jawa Barat. Berdasarkan parameter kondisi gelombang, lokasi dengan kategori sangat layak (66\%) umumnya terletak di perairan antara pulau dan teluk (Gambar 3c). Sekitar 19\% $\left(81 \mathrm{~km}^{2}\right)$ dari lokasi potensial tergolong kategori layak dan $11 \%\left(44 \mathrm{~km}^{2}\right)$ cukup layak. Lokasi dengan kategori tidak layak yang umumnya terletak di perairan terbuka ditemukan sekitar $4 \%\left(17 \mathrm{~km}^{2}\right)$ dari total luasan potensial.

Kedalaman perairan adalah faktor yang penting bagi budi daya rumput laut terutama berkaitan dengan pembuatan media budi daya. Di lokasi penelitian, budi daya rumput laut menggunakan metode long line. Pemilihan lokasi dengan kedalaman yang sesuai (sekitar 

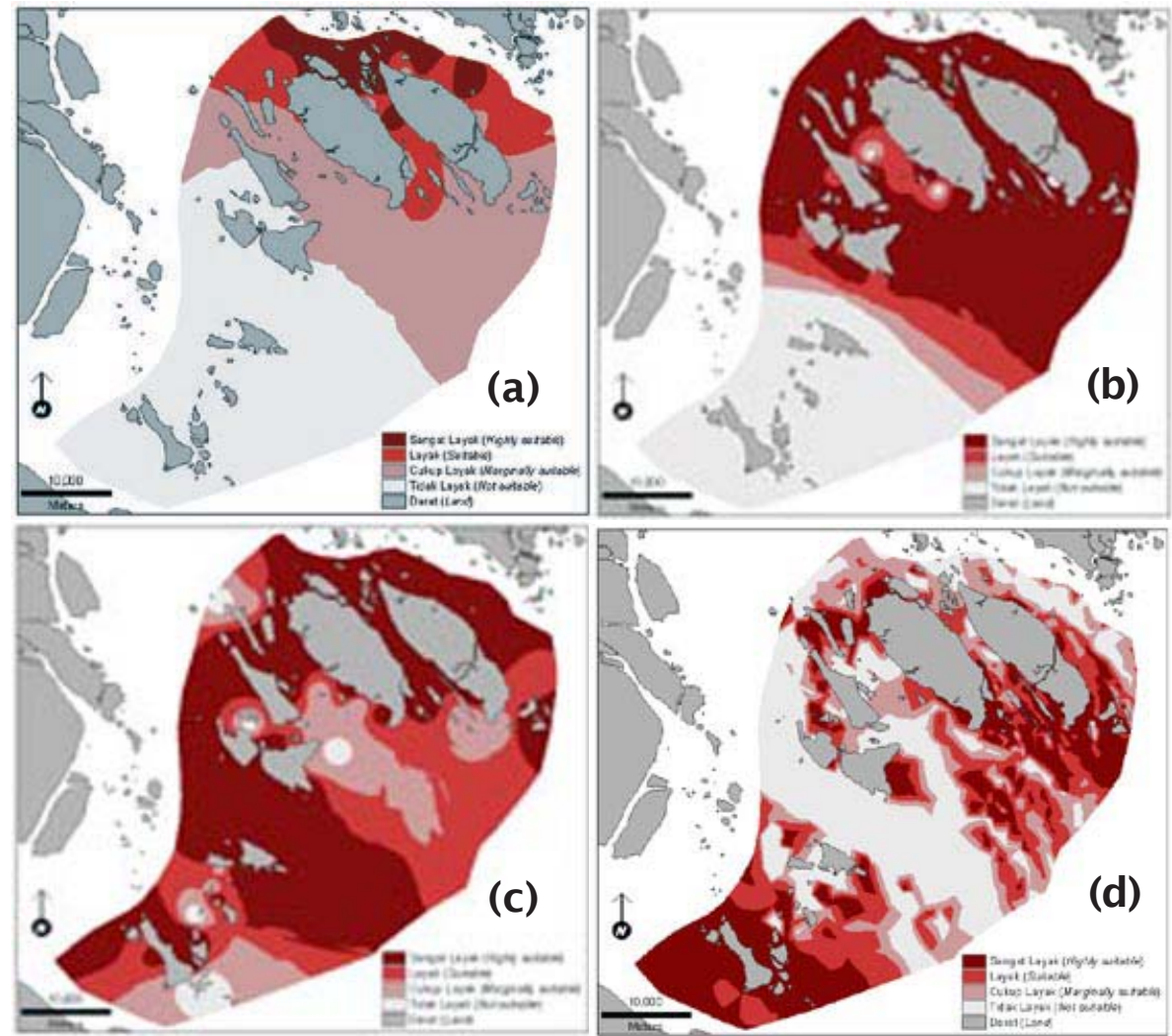

Gambar 3. Tingkat kelayakan perairan parameter lingkungan untuk budi daya rumput laut (a) kecerahan, (b) kecepatan arus, (d) tinggi gelombang, dan (d) kedalaman

Figure 3. Suitability maps of environmental parameter for seaweed culture (a) transparency, (b) water current, (c) wave height, and (d) bathymetry

1--10 m) akan memudahkan untuk melakukan kegiatan budi daya (penanaman dan pemanenan). Berdasarkan kedalaman perairan, sekitar 34\% (143 $\left.\mathrm{km}^{2}\right)$ tergolong sangat layak. Lokasi dengan kategori sangat layak tersebar sekitar Pulau Sugie, Pulau Combol, dan Pulau Durai (Gambar 3d). Sekitar 21\% dan 22\% dari luasan potensial tergolong kategori layak dan cukup layak bagi budi daya rumput laut. Kategori tidak layak ditemukan sebesar 23\% $\left(97 \mathrm{~km}^{2}\right)$ yang terletak diantara Pulau Sangiang dan Pulau Durian.

Kelayakan perairan untuk budi daya rumput laut yang diperoleh dengan menggabungkan peta parameter lingkungan disajikan pada Gambar 4. Dari total luasan potensial untuk budi daya rumput laut (buffer $1 \mathrm{~km}$ dari garis pantai) sebesar $417 \mathrm{~km}^{2}$, kategori sangat layak ditemukan sekitar 110 $\mathrm{km}^{2}$ (26\%). Kategori layak ditemukan sebesar $136 \mathrm{~km}^{2}$ (33\%). Lokasi dengan kategori sangat layak dan layak umumnya tersebar sekitar garis pantai Pulau Sugie dan pulau-pulau kecil di sekitarnya, serta sebagian kecil di Pulau Combol dan Pulau Sugie Bawah (Gambar 4). Perairan bagian selatan lokasi penelitian (Pulau Durai, Pulau Sangiang, dan Pulau Durian) umumnya tergolong kategori cukup layak dan tidak layak dengan besaran masing-masing 132 $\mathrm{km}^{2}$ (32\%) dan $39 \mathrm{~km}^{2}$ (9\%).

Hasil analisis kelayakan perairan telah diverifikasi dengan data keberadaan budi daya rumput laut di lapangan (Gambar 5). Hampir setengah (44\%) dari budi daya yang ada menempati kategori sangat layak. Sekitar 37\% menempati perairan dengan kategori layak dan 13\% kategori cukup layak. Dari seluruh kegiatan budi daya rumput laut yang telah 


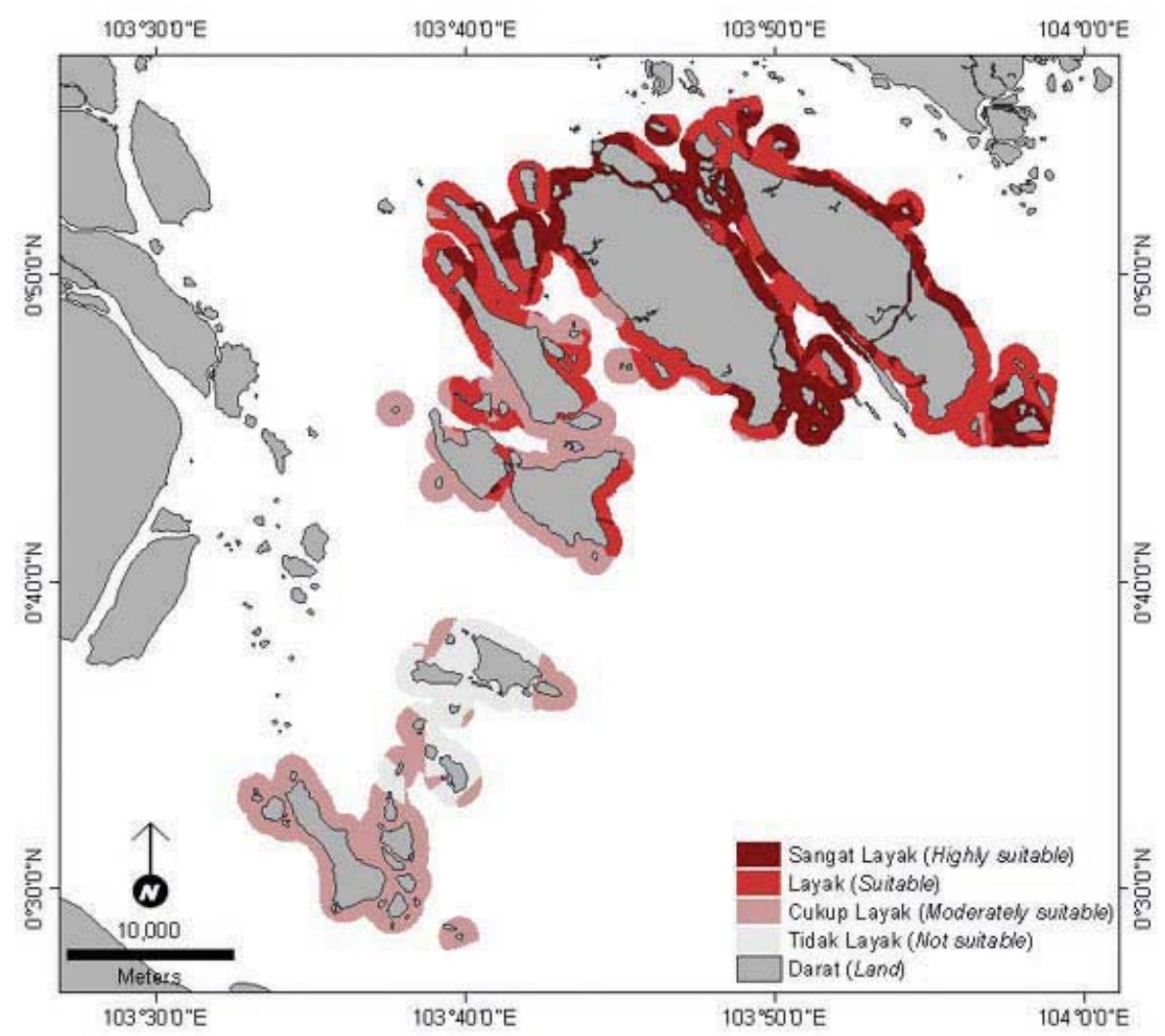

Gambar 4. Peta tingkat kelayakan budi daya rumput laut dengan jarak $1 \mathrm{~km}$ dari garis pantai di perairan Kecamatan Moro

Figure 4. Overall suitability map buffer $1 \mathrm{~km}$ from coastline for seaweed culture in adjacent water of Moro Sub District

berkembang hanya sekitar $6 \%$ yang menempati perairan dengan kategori tidak layak.

\section{Status Peruntukan Lahan Budi Daya Rumput Laut}

Kegiatan budi daya rumput laut umumnya masih merupakan kegiatan sampingan bagi nelayan di sekitar perairan Kecamatan Moro, karena sebagian besar nelayan tersebut melakukan kegiatan penangkapan ikan sebagai mata pencaharian utama (Prihadi et al., 2004). Dibandingkan dengan kegiatan budi daya ikan (menggunakan keramba tancap dan keramba jaring apung.), budi daya rumput laut jauh lebih berkembang, walaupun masih diusahakan secara tradisional dengan jumlah terbatas oleh masyarakat. Rumput laut yang dibudidayakan adalah jenis Eucheuma spp. dengan menggunakan metode long line.
Berdasarkan data Dinas Perikanan dan Kelautan Kabupaten Karimun kegiatan budi daya rumput laut di perairan Kecamatan Moro baru dimanfaatkan sekitar $63 \%$ dari potensi yang ada (Anonim, 2003). Wilayah pemanfaatannya tersebar hampir di semua desa mulai dari Desa Sanglar di bagian selatan sampai di Desa Tanjung Pelanduk di bagian utara (Gambar 5). Potensi yang ada ini didukung dengan keamanan yang baik, karena adanya aturan adat yang masih dipegang teguh oleh masyarakat setempat.

Terlepas dari potensi yang dimiliki, perkembangan kegiatan budi daya rumput laut di Kecamatan Moro memiliki beberapa kendala yang dihadapi di antaranya kondisi perairan yang sangat keruh terutama di perairan sekitar Pulau Durai (saat survai lapangan dilaksanakan tidak ditemui adanya kegiatan budi daya laut 


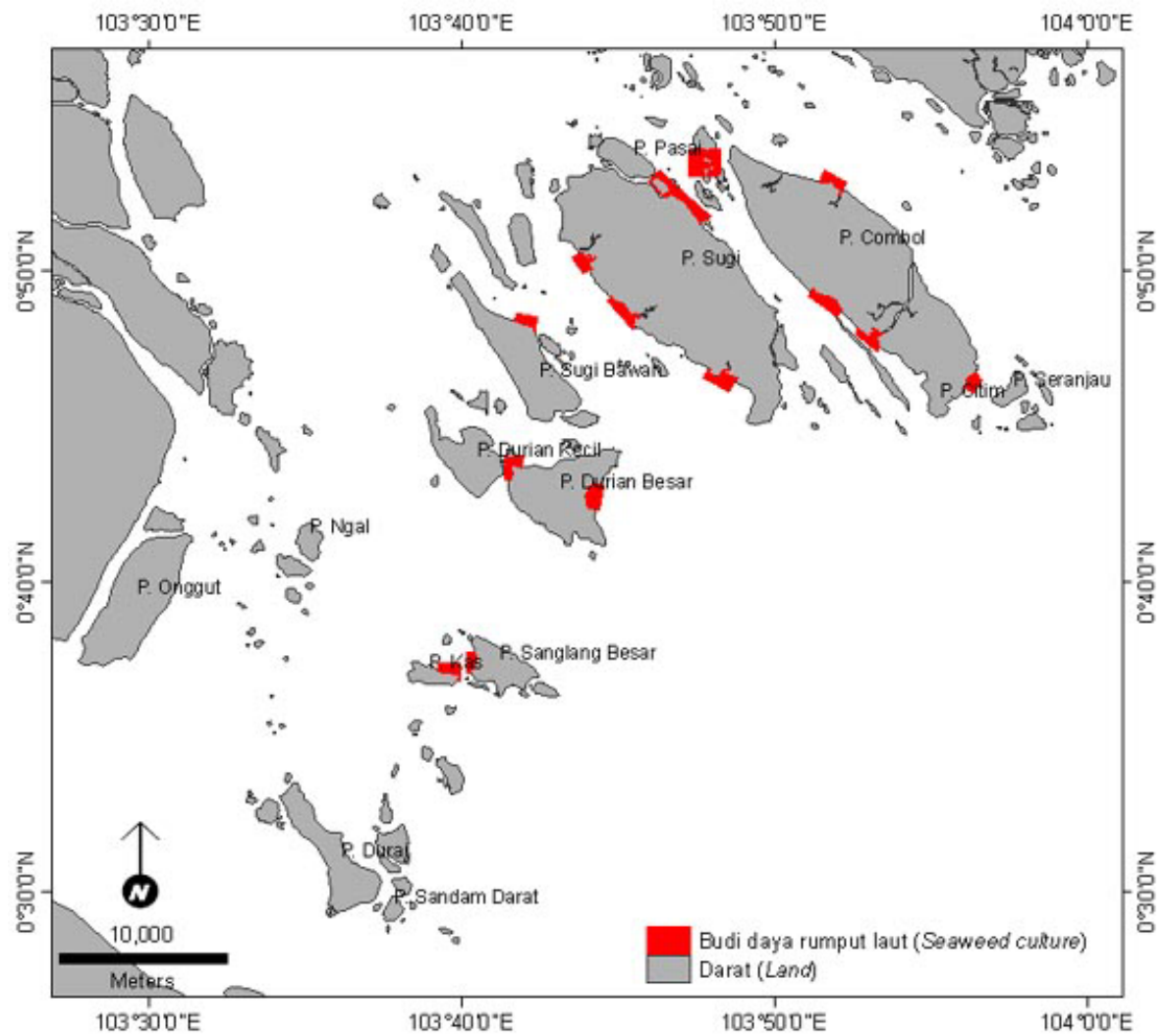

Gambar 5. Sebaran budi daya rumput laut yang ada di lokasi penelitian

Figure 5. Distribution of existing seaweed culture in study area

di lokasi tersebut), kurangnya ketersediaan benih (benih umumnya didatangkan dari Batam), dan masih kurangnya jalur pemasaran rumput laut kering dari nelayan ke pengumpul.

\section{KESIMPULAN}

Dari seluruh parameter lingkungan yang dianalisis, kekeruhan perairan merupakan parameter yang harus menjadi perhatian serius. Parameter ini dapat dikategorikan sebagai kendala bagi pengembangan budi daya rumput laut di lokasi penelitian. Tingkat kekeruhan yang tinggi umumnya ditemukan di selatan lokasi penelitian meliputi Pulau Durai, Sangiang, dan Durian.

Dengan memanfaatkan teknologi SIG, penelitian ini berhasil mengklasifikasi tingkat kelayakan perairan untuk budi daya rumput laut berdasarkan parameter lingkungan perairan. Dari hasil analisis menunjukkan bahwa bagian utara lokasi penelitian (Pulau
Combol dan Sugie) memiliki tingkat kelayakan yang lebih baik dibandingkan dengan bagian selatan (Pulau Durai dan Sangiang). Hal ini sangat sesuai dengan kondisi lingkungan, di mana bagian selatan lokasi penelitian umumnya memiliki kualitas lingkungan yang lebih rendah di bandingkan dengan bagian utara. Penelitian ini hanya memberikan gambaran umum tingkat kelayakan perairan. Kajian yang lebih mendalam yang meliputi berbagai aspek (lingkungan, kualitas perairan, sosial ekonomi, dan infrastruktur) dan menggunakan time series data tentunya akan memberikan hasil yang lebih baik.

Dari hasil analisis tingkat kelayakan dengan kategori sangat layak, baru sebagian kecil saja yang dimanfaatkan untuk kegiatan budi daya rumput laut oleh masyarakat setempat. Hal ini menunjukkan kegiatan budi daya rumput laut masih terbuka luas untuk dikembangkan terutama untuk perairan dengan kategori 
sangat layak. Namun disarankan dalam implementasi pemanfaatan lokasi tersebut harus berpatokan pada kaedah-kaedah lingkungan dan disesuaikan dengan rencana tata ruang pesisir yang telah disusun.

\section{UCAPAN TERIMA KASIH}

Penulis mengucapkan terima kasih kepada Dinas Perikanan dan Kelautan Kabupaten Karimun, Kepala Cabang Dinas Perikanan dan Kelautan Kecamatan Moro, dan Camat Moro yang telah membantu kelancaran pelaksanaan penelitian di lapangan.

\section{DAFTAR PUSTAKA}

Anonim. 2003. Statistik Kecamatan Moro. Kecamatan Moro, Kabupaten Tanjung Balai Karimun, Riau. 20 pp.

Arnold, W.S., -ÿ.W. White, H.A. Norris, and M.E. Berrigan. 2000. Hard clam (Mercenaria spp.) aquaculture in Florida, U.S.A.: geographic information system applications to lease site selection. Aquacult. Eng. 23: 203-231.

Booth, B. 2000. Using ArcGIS 3D analyst. Environmental Systems Research Institute (ESRI). Inc, USA. 218 pp.

Buitrago, J., M. Rada, H. Hernandez, and E. Buitrago. 2005. A single-use site selection technique, using GIS, for aquaculture planning: choosing locations for mangrove oyster raft culture in Margarita Island, Venezuela. Environmental Management. 35. 544--556.

Direktorat Jenderal Perikanan Budidaya. 2006. Statisitk Perikanan Budidaya Indonesia Tahun 2005. Departemen Kelautan dan Perikanan, Jakarta. 136 pp.

FAO. 2007. Global aquaculture production search. < http://www.fao.org/> didownload tanggal 15 Maret 2007.

GESAMP. 2001. GESAMP (IMO/FAO/UNESCOIOC/WMO/WHO/IAEA/UN/UNEP Joint group of experts on the scientific aspects of marine environmental Protection), Planning and management for sustainable coastal aquaculture development. Rep. Stud. GESAMP. 68, 90 pp.

Giap, D.H., Yang Yi, and A. Yakupitiyage. 2005. GIS for land evaluation for shrimp farming in Haiphong of Vietnam. Ocean \& Coastal Management. 48: 51--63.

Johnston, K. and J. McChow. 2001. Using ArcGIS spatial analyst. Environmental Systems Research Institute (ESRI), Inc, USA. 236 pp.
Kapetsky, J.M., L. McGregor, and H. Nanne. 1987. A Geographical Information System and Satellite Remote Sensing to Plan for Aquaculture Development: A FAO-UNEP/ GRID Cooperative Study in Costa Rica. FAO Fish. Tech. Pap. (287): 51 pp.

Karthik, M., J. Suri, N. Saharan, and R.S. Biradar. 2005. Brackish water aquaculture site selection in Palghar Taluk, thane district of Maharashtra, India, using the techniques of remote sensing and geographical information system. Aquacultural Engineering. 32: 285--302.

Malczewski, J. 1999. GIS and mutlicriteria decision analysis. John Wiley \& Sons. New York. 392 pp.

Morain, S. 1999. GIS Solution in Natural Resource Management: Balancing the Technical-Political Equation. OnWord Press. USA. 361 pp.

Mubarak, H., S. Ilyas, W. Ismail, I.S. Wahyuni, S.H. Hartati, E. Pratiwi, Z. Jangkaru, dan R. Arifuddin. 1990. Petunjuk Teknis Budi Daya Rumput Laut. Pusat Penelitian dan Pengembangan Perikanan, PHP/KAN/PT/ 13/1990, Jakarta. 93 pp.

Prihadi, T.H., I N. Radiarta, A. Saputra, O. Johan, J. Hariyadi, dan T. Setiawan. 2004. Riset pemetaan kelayakan lahan budi daya laut. Laporan Proyek Pusat Riset Penelitian Budidaya (unpublised). 25 pp.

Pérez, O.M., T.C. Telfer, and L.G. Ross. 2005. Geographical information system-based models for offshore floating marine fish cage aquaculture site selection in Tenerife, Canary Islands. Aquaculture Research. 36: 946--961.

Saaty, T.L. 1977. A Scaling Method for Priorities in Hierarchical Structures. Journal of Mathematical Psychology. 15: 234--281.

Salam, M.A., G.R. Lindsay, and C.M.M. Beveridge. 2003. A comparison of development opportunities for crab and shrimp aquaculture in south-western Bangladesh, using GIS modeling. Aquaculture. 220: 477-494.

Tiensongrusmee, B. 1990. Site selection for Eucheuma spp. farming. UNDP/FAO Regional Seafarming Development and Demonstration Project (RAS/90/002). Kasetsart University Campus, Bangkok, Thailand. <http://www.fao.org> download 10 Maret 2007. 